Jap. J. M. Sc. \& Biol., 11, 295-305, 1958

\title{
IMPROVEMENT OF THE TECHNIQUES FOR TREPONEMA PALLIDUM AGGLUTINATION TEST
}

\author{
TomoJi TANI, Minoru MATSUBARA, Ryo ITO \\ AND Masao NAKAMUURA \\ Department of Microbiology, Schooi of Medicine, Kanazawa \\ University, Kanazawa, Japan
}

(Received: August 9th 1958)

Serological diagnosis of syphilis by means of agglutination test with Trejonema pallidum as the antigen was first attempted by one of the authors (Tani, 1938, 1940, 1948; Tani and Asano, 1951). Nelson and Mayer (1949) reported the Treponema pallidum immobilization test (T.P.I. test), which then was proven to be of comparatively high specific. Hence, interest was directed towards possibly more simplified agglutination test.

Treponema pallidum agglutination test (T.P.A. test) reported by the author was re-examined by Cain (1953), McLeod and Magnuson (1953), Hardy and Nell (1955), Meinicke (1956), and others.

In order to minimize the occurrence of spontaneous agglutination, Treponema pallidum was treated by antiformin (Tani, 1938, 1940, 1948; Tani and Asano, 1951) and later by bleaching powder (Tani, 1954). The chlorine treated antigens, however, manifested 10 to 15 per cent spontaneous agglutination and retained the specificity for only a short period. Heat treated antigen, which had been reported to be satisfactorily specific, was also found to manifest approximately 10 per cent non-specific agglutination.

Meinicke (1956) stated in his review on the serological reactions for syphilis that T.P.A. test might not be acceptable as a very reliable reaction.

In the mean time, attempts were made to eliminate inert factors contained in serum samples in order to improve the specificity of T.P.A. test. Treatment of serum samples by hydrochloric acid, as reported by Sachs (1921) and Hayes and Sachs (1940), was found to contribute very much in improving the specificity of the reaction.

In the present paper, the experimental results on hydrochloric acid treated serum samples from various sources will be reported. For making comparison, the results with chlorine or heat treated antigens and simply inactivated serum samples, some of which were already reported elsewhere, will also be presented.

\section{Materials AND Methods}

Preparation of the antigen for the improved T.P.A. test: White male rabbits with short

\footnotetext{
* based on the report published in Japanese in Nippon Izi Shimpo, No. 1756, 13-23, 1957.
} 谷友次・松原稔・伊藤良・中村正夫（金沢大学医学部微生物学散室） 
ears indigenous to Japan, aged 4 to 6 months, weighing about $2.5 \mathrm{~kg}$, and with large testicles were favorably used. Aged rabbits, especially those served for breeding, gave rise to changeable incubation period or relatively small number of spirochetes in the testicles. In some individuals no orchitis developed.

One cc of a suspension containing 10 to 50 million spirochetes per cc was inoculated into the middle part of parenchyma of testicles, which usually became swollen in 10 to 14 days. The rabbits were kept in a dark place for about 24 hours before sacrifice by bleeding from carotid artery. Tunica vaginalis, epididymis, fat, etc. were removed carefully from the testicles and only parenchyma was taken. A testicle was usually 6 to $8 \mathrm{~g}$ and some were more than $10 \mathrm{~g}$. The testicles were cut up with scissors as finely as possible.

Two volumes of physiological saline was added to the minced testicles, the mixture was shaken at room temperature for 3 hours at 140 vibrations per minute with an amplitude of 4 to $5 \mathrm{~cm}$, and filtered through double layers of gauze. One cc of the filtrate contained 200 to 300 million spirochetes and in some cases 400 to 500 million. Filtrates containing 50 million or less spirochetes per cc were discarded. Addition of 50 to $100 \mu \mathrm{g}$ hyaluronidase to every cc of saline to hydrolyze hyaluronic acid being abundant in syphilitic testicles (Turner and Hollander, 1953) did not facilitate extraction. Addition of sodium thioglycolate, broth, serum, or neutral phosphate buffer did not facilitate the extraction. Temperature gave no particular influence upon extraction.

Coarse tissue fragments and blood cells were centrifuged down at $100 \mathrm{xg}$ for 10 minutes and the remaining spirochetes were at $5,000 \mathrm{xg}$ for one hour. Each precipitate was mixed thoroughly with $2.0 \mathrm{cc}$ of saline using a pipette. After pooling the suspensions and mixing thoroughly again, saline was added to the weight of the testicle material used. Coarse particles still present were removed by centrifugation at $100 \mathrm{xg}$ for 10 minutes.

The supernatant was dispensed into tubes each with $10 \mathrm{cc}$ and heated in a water bath at $65^{\circ} \mathrm{C}$ for 2 hours. After cooling, one volume of Sörensen's phosphate buffer, $\mathrm{pH} 7.4$, was added to 5 volumes of the suspension, to which a merthiolate solution was added to give a final concentration of $1: 10,000$. The suspensions were allowed to stand at $5^{\circ} \mathrm{C}$ for 3 to 4 days, when the top layers were taken. The spirochete concentration was adjusted to 100 to 200 million per cc with a mixture of 75 per cent of saline, 15 per cent of phosphate buffer, $\mathrm{pH}$ 7.4, and 10 per cent of $1: 1,000$ merthiolate solution. The suspensions were pooled in a glass container and kept at $5^{\circ} \mathrm{C}$ until use.

The antigens thus prepared were assayed on five of Wassermann positive and the same number of negative serum samples according to the procedures described below. Some of the antigens gave no specificity or strong spontaneous agglutination immediately after preparation. However, even such preparations were found to commence the specificity in 12 to 66 days, in average 32 days, when kept standing at $5^{\circ} \mathrm{C}$. The specific antigenicity, once acquired, was stable for over 6 months.

Treatment of serum samples with hydrochloric acid: Treatment of serum samples by hydrochloric acid (Sachs, 1921; Hayes and Sachs, 1940) was found to decrease non-specific reactions in the T.P.A. 'test. The method used by the authors was as follows :

Serum samples were inactivated by heating at $56^{\circ} \mathrm{C}$ for 30 minutes, $0.1 \mathrm{cc}$ of which was dispensed into a tube $(1.2 \times 10.0 \mathrm{~cm})$ to which $0.8 \mathrm{cc}$ of $\mathrm{N} / 400$ hydrochloric acid was added. The mixture was left standing at room temperature for 30 minutes and centrifuged at $400 \mathrm{xg}$ for 15 minutes. The supernatant was added with $0.1 \mathrm{cc}$ of 8.5 per cent $\mathrm{NaCl}$ solution affording 1:10 dilution of the sample. The serum sample thus prepared was stable for 2 to 3 weeks when stored at $5^{\circ} \mathrm{C}$.

Procedures for the improved T.P.A. test: The antigenic fluid was shaken by hand for 5 minutes to well disperse the spirochetes having formed soft cramps during the storage.

A ten-fold dilution of serum sample prepared as above was diluted in a phosphate buffered saline, $\mathrm{pH} 7.4$, to give $1: 20$ dilution. One tenth $\mathrm{cc}$ of each $1: 10$ and $1: 20$ dilutions was dispensed in a small test tube and mixed with the same amount of the antigen. Control 
tubes containing saline, $\mathrm{pH} 7.4$, or $1: 10$ serum samples treated by hydrochloric acid which had been shown to be agglutination positive and negative respectively also received the antigen.

Finally, one drop of 0.2 per cent saponin solution in water, within one week after preparation, was added to each tube. After thoroughly mixing by shaking, the tubes with rubber stoppers were placed in an incubator at $50^{\circ} \mathrm{C}$ for 20 hours. A lower temperature was liable to cause spontaneous agglutination more easily. Although reaction was weakened to some extent, the addition of saponin minimized non-specific agglutination.

Microscopic examination was made in a room at $15^{\circ} \mathrm{C}$ or higher. A drop of the reaction mixture from the bottom was placed on a slide glass by a capillary pipette, covered with a cover glass, and was observed by a darkfield microscope by $\times 300$ magnification.

T.P.A. test with spinal fluid: Untreated spinal fluid samples were serially diluted two-fold. One tenth cc of each dilution was mixed with the same amount of the antigenic fluid. No saponin was added. The reaction was read after incubation at $37^{\circ} \mathrm{C}$ for 20 hours.

Chlorin and heat treatment of antigen and the procedures for the cld T.P.A. test: In earlier experiments, spirochete suspensions were treated by antiformin, bleaching power, or heat with a purpose of eliminating spontaneous agglutination.

Antiformin treated antigen was added to $1: 10$ and $1: 20$ dilutions of simply inactivated serum samples and agglutination was read after 20 hours at $37^{\circ} \mathrm{C}$. Antiformin treated antigen can be used for the test even immediately after preparation but is apt to render spontaneous agglutination in a month or so.

Because of the inconsistent composition of antiformin products in our country, bleaching powder was replaced to it. A product containing 60 per cent of effective chlorine was dissolved in 60 volumes of distilled water and was kept in an refrigerator at $5^{\circ} \mathrm{C}$. The solution containing 1.0 per cent effective chlorine was added to spirochete suspensions to give a final concentration of 0.01 per cent. The mixture was kept at $25^{\circ} \mathrm{C}$ for 30 to 60 minutes and centrifuged. Usually, the bleaching powder treated antigen did not show agglutinability before 2 weeks at $5^{\circ} \mathrm{C}$.

As for heated antigens, $65^{\circ} \mathrm{C}$ for 2 hours (Hardy and Nell, 1955) was found to give the best result.

No particular treatment was given to serum samples except inactivation at $56^{\circ} \mathrm{C}$ for 30 minutes. Incubation of reaction mixtures was at $37^{\circ} \mathrm{C}$.

Wassermann and other tests for syphilis: For making comparisons, Wassermann test and other tests using lipoid antigens, viz. Venereal Diseases Research Laboratory's test (VDRL test) and Murata's test, were run. The old Wassermann test employed a mixture of alcoholic extract of bovine heart muscle and cholesterol as the antigen. The reaction was less sensitive as compared with the one with cardiolipin antigen now used. Later, Ogata's modification (Ogata, 1954) was employed.

Agglutination end titers at L-ratio and S-ratio: According to Ogata et al. (1952, 1954a, 1954b, 1956) and Abe (1957), a syphilitic serum gives the highest agglutination titer when the ratio of cardiolipin $(\mathrm{C})$ : lecithin $(\mathrm{L})$ in the antigen is $1: 10(0.01$ per cent $\mathrm{C}$ and 0.1 per cent $\mathrm{L}$, which was referred to as S-ratio), whereas a leprous serum at $1: 1(0.05$ per cent $\mathrm{C}$ and 0.05 per cent $\mathrm{L}$, which was referred to as L-ratio). If leprosy is complicated with syphilis, the agglutination end titer would be high both at S-ratio and L-ratio. It may be possible, therefore, to detect a complication of syphilis and leprosy. In performing the test, alcoholic solutions of caliolipin and lecithin were mixed to give varying ratios. Agglutination tests were run in the similar way as other syphilitic agglutination tests employing kaolin particles as the receptor and curves of agglutination end titers were drawn.

Serum samples: Ordinary serum samples were obtained from 1,000 individuals in a period from September, 1956 to June, 1957.

Serum samples from pregnant women in 5 th month or later were received from the Kanazawa City Lying-in Hospital and the Obstetrics and Gynecology Department of the 
Central Hospital of Ishikawa Prefecture during a period from February to March, 1957.

Serum samples from lepers were received from the National Leprosarium, Tama Zenshoen in Tokyo in 1957.

Forty serum samples diagnosed as syphilitic and the same number of non-syphilitic by clinical examinations were distributed from the National Institute of Health, Tokyo, in early part of 1957.

\section{EXPERIMENTAL RESULTS}

\section{T.P.A. Tests with Chlorine or Heat Treated Antigens}

These tests were run on simply heat inactivated serum samples by the old procedures. Tests with antiformin treated antigen are shown in Table 1-a and 1-b, which indicate that 10 to 15 per cent non-specific agglutination may be inevitable with the antigen.

Table 1-a. T.P.A. test with antiformin treated antigen (1948)

\begin{tabular}{crrrr}
\hline & T.P.A. test & \multicolumn{2}{c}{-} \\
\hline Old Wa. R.* & 86 & $86(100 \%)$ & 0 & $(0 \%)$ \\
- & 131 & $13(9.9 \%)$ & $118(90.1 \%)$ \\
\hline
\end{tabular}

Rate of agreement: 204 in $217(94.0 \%)$

* Wa. R. in this and the following tables is for Wassermann reaction.

Table 1-b. T.P.A. test with antiformin treated antigen (1953)

\begin{tabular}{crrrr}
\hline & T.P.A. test & \multicolumn{2}{c}{ - } \\
Old Wa. R. & 145 & $141(97.2 \%)$ & $4(2.8 \%)$ \\
+ & 255 & $36(14.1 \%)$ & $219(85.9 \%)$ \\
\hline
\end{tabular}

Rate of agreement: 360 in $400(90.0 \%)$

Table 2. T.P.A. test with bleaching powder treated antigen (1954-1955)

\begin{tabular}{crrrr}
\hline & T.P.A. test & \multicolumn{1}{c}{ - } & \\
Wa. R. (Ogata's) & & $107(98.2 \%)$ & 2 & $(1.8 \%)$ \\
+ & 109 & 5 & $(3.1 \%)$ & $156(96.9 \%)$ \\
\hline
\end{tabular}

Rate of agreement: 263 in $270(97.4 \%)$

Results with the bleaching powder treated antigen are summarized in Table 2. The treatment by bleaching powder gave 97.4 per cent agreement with WassermanOgata's test, which was slightly higher than 94.0 or 90.0 per cent obtained with antiformin treatment. The antigen retained the specificity for only a month or two and developed spontaneous agglutination later, as was the case with the antiformin treated antigen. 
Table 3. T.P.A. test with heated antigen (1956)

\begin{tabular}{|c|c|c|c|}
\hline Wa. R. (Ogata's) & T.P.A. test & + & - \\
\hline+ & 65 & $64(98.5 \%)$ & $1 \quad(1.5 \%)$ \\
\hline- & 155 & $22(14.2 \%)$ & $133(85.8 \%)$ \\
\hline
\end{tabular}

Rate of agreement : 197 in $220(89.6 \%)$

The tests with heat treated antigen are presented in Table 3 . The rate of agreement between T.P.A. test and Wassermann-Ogata's test was slightly lower than those with chlorine treated antigens, but the heated antigen has an advantage being stable for six months or longer after preparation.

\section{The Improved T.P.A. Test with the Variety of Serum Samples Treated by Hydrochloric Acid}

1. Tests on serum samples obtained from ordinary individuals: Shown in Table 4 (a-d) are the results with the improved tests made on one thousand serum samples obtained from ordinary individuals. Comparison of positive rates between the improved T.P.A. test and three of tests for syphilis with lipid antigens is given in Table 4-a, which indicates a notably low rate with Murata's test, the other three giving a same rate, 26.4 per cent.

The rate of agreement between the improved T.P.A. test and each test with lipid antigen is shown in Tables $4-b$, c, and $d$ respectively.

Eighteen individuals whose serum samples gave converse reactions in the T.P.A. test and Wassermann-Ogata's or VDRL test were further investigated for syphilitic infection. Syphilitic infection was confirmed in 4 cases, and another 2 were clinically diagnosed as syphilis. Two of these 6 cases diagnosed as syphilis

Table 4-a. Positive rates by various tests made on ordinary serum samples (1956 to 1957)

\begin{tabular}{ccccc}
\hline $\begin{array}{c}\text { Number of samples } \\
\text { examined }\end{array}$ & $\begin{array}{c}\text { Wassermann- } \\
\text { Ogata's test }\end{array}$ & VDRL test & Murata's test & T.P.A. test \\
\hline 1,000 & $\begin{array}{c}264 \\
(26.4 \%)\end{array}$ & $(26.4 \%)$ & $\begin{array}{c}149 \\
(14.9 \%)\end{array}$ & $(26.4 \%)$ \\
\hline
\end{tabular}

Table 4-b. Comparison of Wassermann-Ogata's test and T.P.A. test on ordinary serum samples

\begin{tabular}{ccccrc}
\hline \hline Wa. R. (Ogata's) & T.P.A. test & \multicolumn{1}{c}{+} & \multicolumn{1}{c}{-} \\
\cline { 1 - 4 }+ & 264 & $258(97.7 \%)$ & 6 & $(2.3 \%)$ \\
- & 736 & 6 & $(0.8 \%)$ & $730(99.2 \%)$ \\
\hline
\end{tabular}

Rate of agreement: 988 in 1,000 (98.8\%) 
Table 4-c. Comparison of VDRL test and T.P.A. test on ordinary serum samples

\begin{tabular}{|c|c|c|c|c|c|}
\hline VDRL test & T.P.A. test & & + & & - \\
\hline+ & 264 & 257 & $(97.3 \%)$ & 7 & $(2.7 \%)$ \\
\hline- & 736 & 7 & $(1.0 \%)$ & 729 & $(99.0 \%)$ \\
\hline
\end{tabular}

Rate of agreement : 986 in $1,000(98.6 \%)$

Table 4-d. Comparison of Murata's test and T.P.A. test on ordinary serum samples

\begin{tabular}{ccrr}
\hline & T.P.A. test & $\boldsymbol{+}$ & \multicolumn{1}{c}{} \\
\hline Murata's test & 149 & $146(98.0 \%)$ & $3(2.0 \%)$ \\
+ & 851 & $118(13.9 \%)$ & $733(86.1 \%)$ \\
\hline
\end{tabular}

Rate of agreement : 879 in $1,000(87.9 \%)$

gave positive reaction in Wassermann-Ogata's test, 5 in VDRL test and 2 in T.P.A. test. No definite information was furnished for the remaining 12 cases.

2. Tests on serum samples from pregnant women: Tests made on serum samples from pregnant women in five months or later gave a rate of agreement, 98.2 per cent, between the T.P.A. test and Wassermann-Ogata's test as can be seen in Table 5.

3. Tests on serum samples from lepers: The T.P.A. test was conducted on serum samples from lepers comparing with other tests with lipid antigens. Positive rates obtained are summarized in Table 6-a. As can be seen in the table, both the T.P.A. test and Wassermann-Ogata's test gave positive rates very close each other between neural type and lepromatous type.

Rates of agreement between the T.P.A. test and each of the other three are shown in Table 6-b.

Twenty-five serum samples tested which gave positive reaction in either Wassermann-Ogata's test or the T.P.A. test were further investigated by determining agglutination end titers at L-ratio and S-ratio. Type of leprosy and the possible complication with syphilis were clinically examined. All 22 serum samples shown to be positive with the T.P.A. test gave high agglutination titers both at

Table 5. Comparison of Wassermann-Ogata's test and T.P.A. test on serum samples from pregnant women (1957)

\begin{tabular}{ccrrr}
\hline Wa. R. (Ogata's) & T.P.A. test & & \multicolumn{1}{c}{-} \\
\cline { 1 - 2 }+ & 3 & $2(66.7 \%)$ & $1(33.3 \%)$ \\
- & 110 & $1(0.9 \%)$ & $109(99.1 \%)$ \\
\hline
\end{tabular}

Rate of agreement : 111 in $113(98.2 \%)$ 
Table 6-a. Positive rates by different tests for syphilis made on leprous serum samples (1957)

\begin{tabular}{ccccc}
\hline Samples examined & $\begin{array}{c}\text { Wassermann- } \\
\text { Ogata's test }\end{array}$ & VDRL test & Murata's test & T.P.A. test \\
\hline Lepromatous type & 18 & $39 \%$ & $13^{*}$ & 18 \\
104 & $(17.3 \%)$ & $(37.9 \%)$ & $(12.6 \%)$ & $(17.3 \%)$ \\
Neural type & 5 & 5 & 5 & 4 \\
41 & $(12.2 \%)$ & $(12.2 \%)$ & $(12.2 \%)$ & $(9.8 \%)$ \\
Total & 23 & $44^{*}$ & $18^{*}$ & 22 \\
145 & $(15.9 \%)$ & $(30.6 \%)$ & $(12.5 \%)$ & $(15.2 \%)$ \\
\hline
\end{tabular}

* One of the lepromatous serum samples was too small amount to perform VDRL and Murata's tests. The percentages were obtained, therefore, from 103 lepromatous serum samples instead of 104 .

Table 6-b. Rate of agreement of positive reactions between T.P.A. test and each of other tests with lipid antigen made on leprous serum samples

\begin{tabular}{cccc}
\hline Type of leprosy & Wa. R. (Ogata's) & VDRL : T.P.A. & Murata's : T.P.A. \\
\hline \multirow{2}{*}{ Lepromatous } & $18: 16$ & $39: 15$ & $13: 8$ \\
Neural & $(88.9 \%)$ & $(38.5 \%)$ & $(61.5 \%)$ \\
Total & $5: 4$ & $5: 4$ & $5: 3$ \\
& $(80.0 \%)$ & $(80.0 \%)$ & $(60.0 \%)$ \\
& $23: 20$ & $44: 19$ & 18.11 \\
\end{tabular}

L-ratio and S-ratio. While, 3 Wassermann-Ogata's positive but T.P.A. negative serum samples were shown to be such low agglutination end titers as 0 to 1 at S-ratio in contrast to high agglutination end titers at L-ratio. Clinical examination detected also no syphilis infection in them. Thus the T.P.A. test and the agglutination end titers at L-ratio and S-ratio brought about well corresponding results.

All of 10 serum samples obtained from syphilitic cases as clinically diagnosed gave positive reaction in the T.P.A. test, while one of them was negative with Wassermann-Ogata's test.

4. Tests on the serum samples received from the National Institute of Health in Tokyo: The results of the T.P.A. test made on 40 syphilitic and the same number

Table 7. T.P.A. test made on the serum samples distributed from the National Institute of Health in Tokyo (1957)

\begin{tabular}{ccrr}
\hline Syphilis & T.P.A. test & \multicolumn{1}{c}{+} \\
\hline+ & 40 & $34(85.0 \%)$ & $6(15.0 \%)$ \\
- & 40 & $1(2.5 \%)$ & $39(97.5 \%)$ \\
\hline
\end{tabular}

Rate of agreement: 73 in $80(91.3 \%)$ 
of non-syphilitic serum samples, which had been tested at the National Institute of Health, are as presented in Table 7. All the non-syphilitic serum samples had been from pregnant women. VDRL test with these samples conducted in the National Institute of Health gave 97.5 per cent agreement with the clinical diagnosis. The figure was slightly higher than that obtained by the T.P.A. test performed by the authors.

\section{T.P.A Test Made on Spinal Fluid Samples}

Table 8-a, which was already reported elsewhere, indicates as high as 98.6 per cent agreement between the T.P.A. test and Wassermann test when applied on spinal fluid samples. Table 8 -b also gives as high as 97.8 per cent agreement between the two tests. Of 20 samples from patients of progressive paralysis, 17

Table 8-a. T.P.A. test made on spinal fluid samples (1948)

\begin{tabular}{crrr}
\hline Old Wa. R. & T.P.A. test & \multicolumn{1}{c}{-} \\
\hline+ & 33 & $33(100 \%)$ & 0 \\
- & 39 & $1(2.6 \%)$ & $38(97.4 \%)$ \\
\hline
\end{tabular}

Rate of agreement: 71 in $72(98.6 \%)$

Table 8-b. T.P.A. test made on spinal fluid samples (March, 1957)

\begin{tabular}{rrrrr}
\hline Wa. R. (Ogata's) & T.P.A. test & \multicolumn{2}{c}{+} & \multicolumn{2}{c}{ - } \\
\cline { 1 - 2 }+ & 17 & $17(100 \%)$ & 0 & $(0 \%)$ \\
- & 28 & $1(3.6 \%)$ & $27(96.4 \%)$ \\
\hline
\end{tabular}

Rate of agreement: 44 in $45(97.8 \%)$

were positive in Wassermann-Ogata's test. One out of the other three which were negative in Wassermann-Ogata's test, gave positive reaction in the T.P.A. test. All of 25 samples from patients of neuropathic disorder excluding progressive paralysis were negative in both T.P.A. and Wassermann-Ogata's tests. One hundred and twenty-seven spinal fluid samples have been tested so far by the authors, and a rate of agreement, 98.4 per cent, between the T.P.A. test and Wassermann test has been obtained.

Ten spinal fluid samples from cases of schizophrenia were tested. All of them turned out to be negative in both Wassermann and T.P.A. tests.

\section{Discussion}

Serological tests for syphilis with cardiolipin antigens may give, as a whole, reliable results, but non-specific reactions have been encountered because the antigens are not the component of the pathogenic agent. Meanwhile, Treponema pallidum immobilization test (T.P.I. test) reported by Nelson and Mayer (1949) has 
attained world's recognition for its excellent specificity. However, the procedures of the T.P.I. test seem to be somewhat too complicated to perform as a routine diagnostic method in our country.

Treponema pallidum agglutination test (T.P.A. test) was first reported by the author (Tani, 1938). However, it was unable to avoid the occurrence of non-specific agglutination at 10 to 15 per cent. Attempts to minimize the non-specific reaction by treating the antigen with antiformin, bleaching powder, or heat were not very successful.

Treating serum samples by $\mathrm{N} / 400$ hydrochloric acid, which had been elaborated by Sachs (1921) and Hayes and Sachs (1940) for removing anticomplement from serum samples for Wassermann test, was attempted in order to remove inert protein in the serum and minimize the non-specific reaction. By this treatment and several other modifications of the procedures, the T.P.A. test attained as high as 98.8 per cent agreement with Wassermann-Ogata's test when applied on serum samples from masses of people. Since clinical detection of both subjective and objective symptoms of syphilis is difficult, as is the case in leprosy, evaluation as to which test gives a higher agreement with the clinical conditions was not feasible. Application of the improved T.P.A. test on serum samples from pregnant women and lepers, or on spinal fluid samples has demonstrated the availability of the test along with the hitherto employed serological tests with lipid antigens.

The improved T.P.A. test brought about a high rate of agreement, 98.2 per cent with Wassermann-Ogata's test on serum samples from pregnant women. According to Saeki (1950), Yoda (1951), Yasui and Kusumoto (1952), and Sasaki (1953), about 3 to 4 per cent of pregnant women might give positive reaction to an immunological test for syphilis and that the rate seemed to be decreasing. The authors' results of Wassermann-Ogata's test conducted in the year of 1957 revealed the rate to be 2.7 per cent and the T.P.A. test gave the same per cent of positive reaction.

It has long been known that the serological tests of syphilis gave rise to nonspecific, positive reaction on leprous serum samples. Ootawara et al. (1944) reported 47.2 per cent lepers gave positive reaction with Wassermann test, lepromatous type being 57.1 per cent and neural type 37.2 per cent. Yoshinaga (1949) reported that 21.3 per cent of lepers gave positive reaction with Wassermann test, lepromatous type being 28.6 per cent and neural type 13.2 per cent. The problem was reviewed in detail by Nojima (1930), Sato (1954), Klingmüller (1930), and Matsuhashi (1952). According to Sato, the positive rate of lepromatous leprosy to Wassermann test was 30 to 80 per cent, while that of neural type was 40 to 50 per cent. According to Nelson (1952), out of 70 lepers 57 (81.4 per cent) were positive to a test with cardiolipin antigen. In the tests conducted by the authors no significant difference in positive rate was found between lepromatous and neural types by the T.P.A. test, Wassermann-Ogata's test, or Murata's test, and the positive rates with these tests were unexpectedly low. Whereas VDRL test gave a high positive rate and markedly different rates between lepromatous and neural types. Twentyfive serum samples which gave positive reaction to either Wassermann-Ogata's or the T.P.A. test were further examined for their agglutination end titers at L-ratio and S-ratio. The T.P.A. test was found to coincide much better with the agglutination end titers. However, because of a considerable number of cases of clinically 
asymptomatic syphilis, it was difficult to conceive of the possible relationship between the serum samples giving positive reaction to the T.P.A. test and the actual syphilitic infection. Yet it can be at least said that the T.P.A test appears to be one of the reliable method to detect syphilis complicated in leprosy.

\section{SUMMARY}

1. Procedures for the improved T.P.A. test were detailed including the preparation of antigen and hydrochloric acid treatment of serum samples.

2. The improved T.P.A. test showed 98.8 per cent agreement with Wassermann-Ogata's test, 98.6 per cent with VDRL test, and 87.9 per cent with Murata's test on 1,000 serum samples from ordinary individuals.

3. The T.P.A. test brought about 98.2 per cent agreement with WassermannOgata's test on 113 serum samples from pregnant women.

4. On examining 145 leprous serum samples, 15.9 per cent were positive with Wassermann-Ogata's test, 30.6 per cent with VDRL test, 12.5 per cent with Murata's test, and 15.2 per cent with the improved T.P.A. test. The agglutination end titer curves at L-ratio and S-ratio well agreed with the T.P.A. test.

5. The T.P.A. test made on 80 serum samples, of which confirmation had been made as to syphilis positive or syphilis negative by clinical examinations, gave 91.3 per cent agreement with the findings of the clinical examinations. The figure was slightly less than 97.5 per cent obtained with VDRL test.

6. The T.P.A. test made on 127 spinal fluid samples brought 98.4 per cent agreement with Wassermann test.

\section{REFERENCES}

ABE, M. (1957) : Agglutination test of leprous sera. "Igaku-no-Ayumi," 23, 408-419 (text in Japanese).

CAIN, R. M. (1953): The phenomenon of treponemal agglutination for the serodiagnosis of syphilis. Canad. J. Pub. Health, 44, 61-66.

H.ARDY, P. H. \& NELL, E. (1955) : Specific agglutination of Trepcnema pallidum by sera from rabbits and human beings with treponemal infections. J. Exper. Med., 101, 367-382.

HAYES, W. \& SACHS, H. (1940): Anticomplementary action of serum and the Wassermann reaction. J. Path. \& Bact., 51, 455-458.

KlingmulleR, (1930): Die Lepra, Serologie, Handbuch der Haut- und Geschlechtskrankheiten, $X / 2,142-167$.

MATSUHASHI, C. (1952) : False positive reactions in the serological tests of syphilis. "Igakuno-Ayumi," 14, 262-269 (text in Japanese).

McLeod, C. P. \& MAgnuson, H. J. (1953): Agglutination of Treponema pallidum in syphilitic serums. Pub. Health Rep., 68, 747-755.

MEINICKE, K. (1956): Antigen-Antikörperreaktionen mit Apathogenen und Virulenten Treponemen. Der Hautarzt, 7, 489-497.

NELSON, R. A. (1952): Changing concepts in the serodiagnosis of syphilis: Specific treponemal antibody versus Wassermann reagin. Brit. J. Venereal Dis., 28, 160-168.

NFLSON, R. A. \& MAYER, M. M. (1949): Immobilization of Treponema pallidum in vitro by antibody produced in syphilitic infection. J. Exper. Med., 89, 369-393.

NoJIMA, T. (1930): Studies on the seroreactions of leprosy. I. Wassermann reaction and leprous serum. Lepra, 1, 1-26 (text in Japanese).

Ogata, T., Hara, I., Abe, M., Tokunaga, E. \& Matsuhashi, C. (1952) : New serological 
reactions of leprous sera. I. Agglutination test. "Nisshin-Igaku," 39, 468-477 'text in Japanese).

OGATA, T. (1954): New serological techniques of syphilis diagnosis. 2nd Ed., Nanzando, Tokyo (text in Japanese)

Ogata, T., Hara, I., Abe, M., Tokunaga., E., Matsuhashi, C., Yoshie, Y., Hokibara, H. \& TAKAHASHI, S. (1954a): New serological reactions of leprous sera. II. Observations in relation to clinical pictures. "Nisshin-Igaku," 41, 104-107 (text in Japanese).

OGATA, T., ABE, M. \& HARA, I. (1954b): New serological reactions of leprous sera. III. Properties of leprous antibodies, especially the difference from syphilitic antibodies. "Nisshin-Igaku," 41, 477-487 (text in Japanese).

Ogata, T., ABE, M. \& TAKAhAShI, S. (1956). New serological reactions of leprous sera. IV. Presence of typical and atypical antibodies in leprous sera and their distribution in serum fractions. "Nisshin-Igaku," 43, 207-217 (text in Japanese).

Ootawara, T., IchiHARA, T., TADA, K. \& SusukI, K. (1944): Studies on leprosy. XIII. Analytical investigation on the complement-fixing substances, contained in leprous sera. "Nippon-Igaku," No. 3376, 530-535 (text in Japanese).

SACHS, H. (1921): Ein Hilfsmittel für die Methodik der Wassermannschen Reaktion. Berl. Klin. Wschr., 58, 1075-1076.

SAEKI, T. (1950) : Findings of the examinations made on pregnant women at Health Centers. I. On the serodiagnosis of syphilis. "Nippon-Sanka-Fujinka-Gakkai-Zasshi," 2, 505-510 (text in Japanese).

SASAKI, T. (1953): Syphilitic serodiagnosis of pregnant women during the last 3 years. "Koshu-Eisei," 13, 82-83 (text in Japanese).

SATO, S. (1954): Serology of leprosy. "Nippon-Hifuka-Zensho," IX/1, 40-48 (text in Japanese).

TANI, T. (1938): Studies on agglutination reaction of Treponema pallidum. "Juzenkai-Zasshi," 43, 3149-3169 (text in Japanese).

TANI, T. (1940): Untersuchungen über die Agglutination der Syphilis-spirochäten. Jap. J. Exper. Med., 18, 11-37.

TANI, T. (1948): On the agglutination of Treponema pallidum. "Nisshin-Igaku," 35, 102104 (text in Japanese).

TANI, T. (1954): Problems related with the immunity of syphilis. "Sogo-Igaku," 3, 10691079 (text in Japanese).

TANI, T. \& AsANO, O. (1951): Studies on the agglutination of Treponema pallidum. II. On the agglutination of Treponema pallidum treated with antiformin in human serum and cerebrospinal fluid. Jap. M. J., 4, 51-53.

Turner, T. B. \& HOLlander, D. H. (1953): The effect of ACTH and cortisone upon infection and resistance. Chapter 9. Studies on the mechanism of action of cortisone in experimental syphilis. Edited by G. Shwartzman, Columbia University Press.

YASUI, S. \& KUSUMOTO, M. (1952) : Distant effects of anti-syphilitic therapy and serodiagnosis of syphilis. "Nippon-Iji-Shimpo," No. 1464, 1593-1596 (text in Japanese).

YODA, G. (1951): Serodiagnosis of pregnant women made with cardiolipin antigen. "KoshuEisei," 10, 218-219 (text in Japanese).

YoshinAGA, T. (1949): Complement-fixing reaction of leprous sera. III. Wassermann reaction and complement-fixing reaction with kephalin-antigen. Lepra, 18, 57-58 (text in Japanese). 